\title{
APPLICATION OF SUSTAINABLE SYSTEMS OF MILK PRODUCTION ON SMALL FARMS **
}

\author{
M. P. Petrović ${ }^{*}$ Lj. Sretenović, S. Aleksić, D. Ružić-Muslić, M. \\ Žujović, N. Maksimović ${ }^{1}$ \\ ${ }^{1}$ Institute for Animal Husbandry, Belgrade-Zemun, 11080 Zemun \\ * Corresponding author:Milan Petrović, e-mail: milanppet@yahoo.com \\ **Original scientific paper - Originalni naučni rad \\ Research was financed by the Ministry of Science of Republic of Serbia within project TR \\ 20042/08 - Rad je finansiran od strane Ministarstva za nauku Republike Srbije u okviru projekta \\ TR 20042/08
}

Abstract: In this paper current situation is analyzed and sustainable systems introduced in production of milk on small farms. Old production systems used on farms were the reason why milk production wasn't profitable activity and therefore livestock production in mountainous regions had complete collapse and pastures remained almost entirely deserted.

In population of Pirot Pramenka sheep and local Simmental population of cattle, our analysis of breed productivity shows that effects in milk production are bad.

Application of sustainable systems of milk production would increase the milk yield and revive dairy livestock production.

After application of new systems regarding of breeding and farm management, milk yield in sheep cows was increased in average by $12 \%$.

Key words: new systems, milk production, sheep, cattle

\section{Introduction and literature review}

Milk production depends on many factors and it is specific in conditions of transformation of the economy of Serbia. In countries of the European Union attention is directed towards production systems and marketing (Gabina, 2006). Special attention is directed to new techniques for sustainable production and milk quality (Moio et al.,1996, ,Serradilla, 2002). 
Serbia disposes with great natural potentials for development of dairy livestock production, especially in the hilly-mountainous regions which makes $85 \%$ of total Serbia In this region, sheep and cattle are traditionally raised as domestic animals which can most efficiently use the existing resources through grazing. This lead to famous products with historical background such as: Pirot hard cheese (kachkaval), Sjenica cheese, cheese from Homolje, and many other types of cheeses made of sheep or cow milk which were sold on domestic market but also exported to other markets.

In the last decades, old production systems used on farms were the reason why milk production wasn't profitable activity and therefore livestock production in mountainous regions collapsed completely and pastures remained almost entirely deserted (Petrović et al. 2005, Ružić-Muslić,et al., 2005). Introduction of sustainable system sof milk production would considerably increase the milk yield of sheep and cows and motivate the rural population to revive dairy livestock production (Serradilla ,2002, Petrović, 2007).

The objective of this paper is to present some of the results obtained by introduction of sustainable systems for milk production on small farms.

\section{Material and methods}

Researches were carried out on the Stara Planina Mountain on smallholder farms. Investigation included family farms which were engaged in breeding of sheep and cattle. Sheep included in the research were of Pirot population and cattle of Domestic Simmental breed.

Grasslands and hay samples were analyzed as part of the research. Also the method and quality of nutrition of sheep and cattle were investigated. Improved and balanced diets were composed based on different productions and new recommendations regarding housing and care were also made.

Milk recording was carried out using standard method once a month during the entire period of lactation. Laboratory analysis of milk was performed in dairy plant Dojkinci as well as in authorized institutions in Belgrade.

Processing of data was done using modern methods which are applied in specific fields of research.

\section{Results and discussion}

Results of the investigation of the quality of hay are presented in table 1. 
Table 1. Average chemical composition of hay from natural grasslands (\%)

Tabela 1. Prosečni hemijski sastav sena sa prirodnih travnjaka (\%)

\begin{tabular}{|l|l|l|l|l|l|}
\hline Grassland/Travnjak & $\begin{array}{l}\text { Dry } \\
\text { matter/ } \\
\text { Suva mat. }\end{array}$ & $\begin{array}{l}\text { Mineral } \\
\text { matter/ } \\
\text { Min. mat. }\end{array}$ & $\begin{array}{l}\text { Organic } \\
\text { matter/ } \\
\text { Org. mat. }\end{array}$ & $\begin{array}{l}\text { Crude } \\
\text { protein/ } \\
\text { Sir. } \\
\text { prot. }\end{array}$ & $\begin{array}{l}\text { Crude } \\
\text { fibre/ } \\
\text { Sir. } \\
\text { vlak. }\end{array}$ \\
\hline Gabar, $900 \mathrm{~m}$ & 88.19 & 7.64 & 81.85 & 12.42 & 20.22 \\
\hline Planina, $1200 \mathrm{~m}$ & 86.18 & 5.25 & 80.61 & 6.42 & 28.96 \\
\hline Ponor, $1500 \mathrm{~m}$ & 85.88 & 5.01 & 80.12 & 5.31 & 31.53 \\
\hline
\end{tabular}

From data presented in table we can see that chemical composition of samples varied depending on the altitude, in other words, in our case, grasslands located on lower altitudes had better quality of hay. There are correlation between grassland management and animal product quality (Sheath et al, 2001).

Traditional diets for cows and sheep in summer period consisted of cut meadow grass or grazing/pasture with $11 \%$ proteins in average. However, such nutrition is not adequate and only through strictly controlled and balanced diets it is possible to realize good production, reproduction and health results (Sretenović et al, 2005, Martin et al, 2005).

Application of new balanced diets for sheep and cattle were made and they are presented in tables 2 and 3.

Table 2. Composition of diet for sheep in lactation

Tabela 2. Sastav obroka za ovce u laktaciji

\begin{tabular}{|l|l|l|l|c|c|c|c|}
\hline $\begin{array}{l}\text { Components/ } \\
\text { Sastojci }\end{array}$ & $\mathrm{kg}$ & $\mathrm{DM}$ & $\mathrm{UF}$ & $\mathrm{PDIN}(\mathrm{g})$ & PDIE & $\mathrm{P}$ & $\mathrm{Ca}$ \\
\hline $\begin{array}{l}\text { Meadow hay/ } \\
\text { Livadsko seno }\end{array}$ & 1.6 & 1.4 & 0.8 & 67 & 88 & 2.8 & 6.1 \\
\hline $\begin{array}{l}\text { Wheat, grain/ } \\
\text { Pšenica, zrno }\end{array}$ & 0.50 & 0.43 & 0.5 & 37 & 47 & 1.6 & 0.3 \\
\hline Total/Ukupno & & 1.83 & 1.13 & 104 & 135 & 4.4 & 6.4 \\
\hline Needs/Potrebe & & 1.80 & 1.14 & 109 & 109 & 5.0 & 8.6 \\
\hline
\end{tabular}


Table 3. Composition of improved diet for cows in lactation

Tabela 3. Sastav poboljšanog obroka za krave u laktaciji

\begin{tabular}{|l|c|c|c|c|c|c|}
\hline $\begin{array}{l}\text { Feed/ } \\
\text { Hranivo }\end{array}$ & $\mathrm{kg}$ & $\mathrm{DM}$ & $\mathrm{CPC}$ & $\mathrm{NEL}$ & $\mathrm{Ca}$ & $\mathrm{P}$ \\
\hline Hay/Seno & 18 & 15,3 & 684 & 71,1 & 108 & 37,8 \\
\hline $\begin{array}{l}\text { Pasture/grazing/ } \\
\text { Ispaša }\end{array}$ & 9 & 1,5 & 288 & 10,2 & 23,4 & 10,8 \\
\hline $\begin{array}{l}\text { Wheat bran/ } \\
\text { Pšen. mekinje }\end{array}$ & 1 & 0,9 & 120 & 6,14 & 1,2 & 11,2 \\
\hline Whey/Surutka & 2,5 & 0,2 & 22,5 & 1,4 & 1 & 1 \\
\hline Total/Ukupno & - & 17,9 & 1114 & 88,8 & 133 & 60,8 \\
\hline $\mathrm{NaCl}$ & 0,04 & - & - & - & - & - \\
\hline
\end{tabular}

From data presented in table 4 it can see that result of application of sustainable systems is increasing of average milk yield per sheep by $12 \%$ and increasing the average daily milk quantity per cow for $13 \%$. From other hand the health condition of the udder was improved and somatic cell count was decreased. We can see too that the milk from both animal species has normal content of fat and protein which is especially important in cheese production (Pešić Mikulec et al, 2005).

Table 4. Average values of milk quantity and quality before and after application of sustainable systems

Tabela 4. Prosečne vrednosti kvantiteta i kvaliteta mleka pre i posle aplikacije održivih sistema

\begin{tabular}{|c|c|c|c|c|c|c|c|c|}
\hline \multirow{2}{*}{$\begin{array}{l}\text { Species of } \\
\text { Farm/ } \\
\text { Vrsta } \\
\text { farme }\end{array}$} & \multicolumn{2}{|c|}{$\begin{array}{l}\text { Milk yield/ } \\
\text { animal/day } \\
\text { (1)/Prinos } \\
\text { mleka/grlo/dan } \\
\text { (1) }\end{array}$} & \multicolumn{2}{|c|}{$\begin{array}{l}\text { Milk Fat/Ml. } \\
\text { mast } \\
(\%)\end{array}$} & \multicolumn{2}{|c|}{$\begin{array}{l}\text { Milk } \\
\text { Protein/Ml. } \\
\text { protein } \\
(\%)\end{array}$} & \multicolumn{2}{|c|}{$\begin{array}{l}\text { Somatic cell count } / \mathrm{Br} \text {. } \\
\text { somatskih ćelija } \\
(\mathrm{No} / \mathrm{ml})\end{array}$} \\
\hline & $\begin{array}{l}\text { Before/ } \\
\text { pre }\end{array}$ & $\begin{array}{l}\text { After/ } \\
\text { posle }\end{array}$ & $\begin{array}{l}\text { Before/ } \\
\text { pre }\end{array}$ & $\begin{array}{l}\text { After/ } \\
\text { posle }\end{array}$ & $\begin{array}{l}\text { Before/ } \\
\text { pre }\end{array}$ & $\begin{array}{l}\text { After/ } \\
\text { posle }\end{array}$ & Before/pre & $\begin{array}{l}\text { After/ } \\
\text { posle }\end{array}$ \\
\hline Cow/Krava & 9,18 & 10,40 & 3,98 & 3,96 & 3,52 & 3,51 & 350.000 & 280.000 \\
\hline Sheep/Ovca & 0,39 & 0,44 & 7,04 & 7,01 & 5,44 & 5,42 & 370.000 & 300.000 \\
\hline
\end{tabular}




\section{Conclusion}

Based on performed researches, obtained and processed results the following can be concluded:

- Chemical composition of hay samples varied depending on the altitude, and it was established that grasslands in lower regions have better hay quality;

- Application of sustainable systems increasing of average milk yield per sheep by $12 \%$ and increasing the average daily milk quantity per cow for $13 \%$;

- After the application of sustainable systems the health condition of the udder was improved and somatic cell count was decriased within the limits regulated by law.

\section{Primena održivih sistema za proizvodnju mleka na malim farmama}

M. P. Petrović, Lj. Sretenović, S. Aleksić, D. Ružić-Muslić, M. Žujović, N. Maksimović

\section{Rezime}

U ovom radu se analizira postojeća situacija i uvode održivi sistemi u proizvodnju mleka na malim farmama. Stari proizvodni sistemi koji se koriste na farmama su razlog zašto proizvodnja mleka nije bila profitabilna aktivnost, što je dovelo do kolapsa stočarske proizvodnje u planinskim oblastima I skoro napuštenih pašnjaka.

U populaciji pirotske pramenke i lokalne simentalske populacije goveda, naša analiza produktivnosti pokazuje da rezultati u proizvodnji mleka nisu bili dobri.

Primena održivih sistema u proizvodnji mleka bi povećala prinos mleka i oživela proizvodnju u stočarstvu.

Nakon primene novih sistema odgoja i upravljanja, prinos mleka kod ovaca i krava je povećan u proseku za 12\%.

Ključne reči: novi sistemi, proizvodnja mleka, ovce, goveda 


\section{References}

GABINA D (2006): The future of sheep and goat production in Europe: prospects within the framework of new support regimes and market conditions. Small Ruminant Research. Vol 62 Iss.3, 159-165.

MOIO, L. RILLO, A. LEDDA A, ADDEO F (1996): Odorous constituents of ovine milk, J. Dairy Sci. 79 , pp. 1322-1331

MARTIN B., A. CORNU, N. KONDJOYAN, A. FERLAY, I. VERDIERMETZ, P. PRADEL, E. ROCK, Y. CHILLIARD, J.B. COULON AND J.L. BERDAGUÉ(2005): Milk indicators for recognizing the types of forages eaten by dairy cows. In: J.F. Hocquette and S. Gigli, Editors, Proceedings of the European Association of Animal Production Publication on Indicators of Milk and Beef Quality, vol. 112 Bled, Slovenia (2005), pp. 127-136.

PETROVIĆ P.M., V. CARO PETROVIĆ (2005): Shepherding and sheep production in the region of mountain Stara planina-Serbia. 3rd World Congress of Shepherds. Spain, 21-24. September. Book of Communications, 27-30.

PETROVIC P.M (2007): Sustainable sheepbreeding (Održivo ovčarstvo). Institute for Animal Husbandry, Belgrade, 256 p.p.

PEŠIĆ MIKULEC D., M.P.PETROVIĆ, D. RUŽIĆ (2005): Research the quality of row milk for production pirot katchaval. 8. International symposium Modern Trends in Livestock Production-Belgrade. Biotechnology in Animal Husbandry, 5-6, book 2,43-48..

RUŽIĆ-MUSLIĆ D., D. NEGOVANOVIĆ, M.P. PETROVIĆ (2005): Effect of different concentrations of diets for fattening lambs on degradability of nutritive substances. Journal of Animal Science, 5, 74-78.

SERRADILLA J.M.(2002): New techniques for sustainable sheep and goat production. Course material. Tunis, 12. 9-20.

SHEATH G.W., COULON J.B, YOUNG O.A. (2001): Grassland management and animal product quality, Proceedings of the XIX International Grassland Congress Sao Paulo, Brazil pp. 1019-1026.

SRETENOVIĆ LJ., ALEKSIĆ S PETROVIĆ M.M, PETROVIĆ P.M., MARINKOV G, STOJANOVIĆ LJ. (2007): Application of modern technologz of nutrition in high yieling cows in dry period and early lactation. Biotechnology in Animal Husbandry, 1-2,29-41. 